\title{
Economic Theory and the Explanation of Poverty
}

\section{Sikander Rahim*}

This article is an attempt to explain why poverty has persisted to a great extent in Pakistan, despite sustained growth of national income, and to review two publications dealing with poverty and social development, "Social Development in Pakistan: Annual Review 1999, Social Development in Economic Crisis", published by the Social Policy and Development Centre, (SDP) and "Human Development in South Asia, 1999: The Crisis of Governance”, published by the Mahbub ul Haq Human Development Centre (HD).

\section{I: Neo-Classical Theory's Problem: Markets or Policies?}

\section{Two ways of writing on poverty}

Alleviating poverty in developing countries has, over recent years, been receiving more and more emphasis from donors of foreign assistance, especially the World Bank and the IMF. On the face of it, the reason is the disappointment with the consequences of policies that laid too much stress on economic growth and not enough on how its fruits were shared. Supposedly the premise of these policies was that the higher income from economic growth would accrue to the poor, as well as to the rich, and this did not happen, or, at least, it happened so little that the numbers of poor have scarcely fallen in most developing countries and have increased in several faster than the population.

The failure of growth to reduce poverty more than it has done has provoked a large amount of writing on how poverty can be alleviated or removed. This writing can be divided into two types. One is concerned with the mechanisms and institutions that enable the poor to increase their incomes and improve their living conditions. It is primarily microeconomic and institutional, much of the institutional aspect being related to the communities to which the poor belong, and their functions include a wide range of activities, such as repayment of micro-credits, starting and running schools and improving sanitation and water supply. It does not necessarily claim to explain why poverty persists despite economic growth, but incompetent state. Not much need be said in the present article about this type of writing; it stands on its own merits and would be needed even if government policies had had better results.

\footnotetext{
* The author is Professor of Economics at the Lahore School of Economics.
} 
The second type of writing is more general in nature and more concerned with general government policies. When it proposes apparently specific measures, such as decentralisation, community based organisations and self-help schemes, it does not enter into the details of how such measures can or should be made to work, in contrast to the first type of writing on poverty, for which the success of the measures depends on how they are implemented. One would have expected the second type of writing to examine and explain the persistence of poverty, but surprisingly little of it makes any attempt to do so. Mostly it advocates policies without giving any reason to believe that these policies are related to the causes that perpetuate poverty or that they will remove or counteract them. Instead of analysis it provides an abundance of description, illustrations and journalistic devices. When financed by foreign agencies, this results in glossy publications with photographs, coloured charts, boxes, personal anecdotes and the various visual devices used in magazines and advertising to hold the casual reader's attention and to influence him, yet not oblige him to follow a coherent discussion with a critical mind.

Not surprisingly, these publications resemble the World Bank's "World Development Reports" and other publications of international organisations intended for a wide public that includes government officials and politicians. The world Bank has, with time and with the help of outside professionals, learnt how to make its publications highly persuasive to the casual reader. Government officials and politicians are not usually experts, they have neither the training nor the time to examine the facts and reasoning presented in these publications critically, let alone to formulate alternative views. They must take on trust much of what the experts tell them and, if those they believe to be experts seem convincing because they have acquired the skills of the advertising business, officials and politicians are likely to be influenced. And even if they are not persuaded on specific points, in the long run their broad outlook and their way of interpreting economic developments are determined by the unceasing flow of publications of the World Bank and kindred institutions, which are, therefore, most effective in determining economic policy in developing countries.

\section{Political and economic agendas}

Such an elaborate effort to persuade only has a point if the institution behind it has an agenda. That the World Bank and the IMF are acting at the behest of the developed countries, particularly the US, to liberalise trade, privatise public enterprises, reduce state leadership of and direct suppo0rt for industrialisation and to allow capital to flow freely across frontiers is well known. Less obvious is that much of the type of writing on poverty under review here has a similar agenda, the only difference of 
substance being that those who write on poverty can not at the same time advocate relaxing controls on the outflow of capital. It is this conformity to the agenda of the bilateral and multilateral sources of assistance that accounts for the network of internationally prominent people on the boards and panels of the institutions behind these writings and the foreign financing for their expensive publications.

\section{Poverty as a Problem for Neo-Classical theory}

The reason for the superficiality of the second type of writing is the inability of orthodox neo-classical economic theory - and the World Bank and the IMF, in particular, are thoroughly orthodox - to come to grips with the subject of poverty. Neo-classical theory maintains that when markets function freely, the earnings of labour and other factors of production are determined by their marginal products, i.e. by the technical features of production, about which nothing can be done, and that this is efficient in the Pareto sense that nobody can be made better off without somebody else being made worse off. If poverty occurs when markets function freely, it is part of an efficient outcome.

For the economist who adheres to neo-classical theory and wishes to make an issue of poverty, the extent to which the theory determines outcomes by the technical features of production raises the question of how much can be done to remove or alleviate poverty. In other words, if the economy left to itself is deterministic and efficient, what can and should economic policy do? In particular, what should it do in Pakistan?

To this the orthodox economist has two answers. One is to assert that markets work and that the outcome is Pareto efficient, but that a more even distribution of income is, all the same, desirable. In this case poverty is not the result of bad policies, but suitable taxes and transfers of income can yield a better outcome. The alternative answer is to assert that markets fail to work as they should in some parts of the economy and that this is what causes poverty. In this case, not only may the policies pursued by the government have caused the market failures and, therefore, poverty, but adoption of suitable policies will be the cure. Policy can then be both cause and remedy.

Nevertheless, the importance of policy is limited; the most that can be expected of it is to correct for market failure and to redistribute income by fiscal means. If this is all that policy does or can do, the only advice economists can give is, allow markets to function freely, except in the few cases where there is market failure, and, otherwise, use progressive taxation to subsidise some of the consumption and investment of the poor. 
The question is, does this suffice? Will it prevent the incidence of poverty from rising and help the poor increase their incomes? Although some orthodox economists may believe it will, there seems to be no coherent analysis to justify the belief. To be cogent such an analysis should show how market failure, whether the result of policy or not, does not prevent the economy from growing faster than the population, but does prevent income from "trickling down". It would have to specify the form of each market failure, explain how it affects income and growth, as compared to what they would have been in its absence, and show how it can be remedied. Then, if the economist wished to redistribute income as well, he would have to show that the taxes and income transfers, coupled with the steps to remedy the market failure, will not affect the growth and distribution of income so as to offset the gains. There is no lack of writings in which explanations of poverty are couched in terms of generalities, but the present author is not aware of any that satisfy the conditions for cogency just given. In other words, although the possibility exists that neo-classical theory can provide a satisfactory explanation of poverty, there is no such explanation at present, at least for Pakistan, and, consequently, no reason to believe that remedies derived from neo-classical theory will be effective.

Since neo-classical theory has not yet provided a cogent explanation of poverty, at least for Pakistan, the question arises, can it provide one? In other words, can market failure really explain poverty? Or must some other explanation be sought? An idea of how market failure might result in poverty can be obtained by examining what is probably its most prominent case, namely education.

According to neo-classical theory, education is a form of capital invested in people, human capital. An educated worker, therefore, earns, in addition to the wage given by the marginal product of labour, a return on his human capital. Since the marginal product of labour is low in Pakistan, it is the income from human capital that allows a worker to rise out of poverty. But the poor do not have the money to pay for education and market failure prevents banks and enterprises that would benefit from a better educated labour force from financing them. So, unless the state ensures that education is provided to the poor, poverty will persist. And when the state finances education for the poor, it both corrects for a market failure and redistributes income by taxing the less poor to obtain the financing.

The defect of this explanation is that it assumes what needs to be explained. It assumes that the marginal product of labour is so low that uneducated workers must necessarily be poor. The cause of poverty is, therefore, the low marginal product of labour, which is taken as given. The ability of education to reduce poverty in the neo-classical theory is simply a 
result of the treatment of education as a form of capital and the usual relation whereby more capital yields more income. However plausible it may be that the marginal product of labour is so low in Pakistan as to keep an uneducated worker in poverty, it is still an assumption. Then, the desirability of investing in education is also an assumption, for education is simply a form of capital formation whose economic rate of return must be compared to that of other forms of capital. One must bear in mind that economic growth has been high enough to raise income per head and, if, after comparing the rates of return, the economist decides that physical capital is preferable to human capital, the market failure is irrelevant.

If market failure can not convincingly explain why poverty has been so persistent, despite continuous economic growth, i.e. why the increase in income has not "trickled down", two conclusions follow. One is that neoclassical theory can not explain poverty and, therefore, that policies to alleviate it that follow from the theory have no justification. The second conclusion is that the causes of poverty must have been the policies pursued by the government. This means that, knowingly or not, governments have chosen policies that kept the incomes of the lower income groups down, when they could have chosen other policies that would have allowed these incomes to rise.

What follows is an attempt to show briefly how government policies have affected income distribution in Pakistan and, therefore, the incidence of poverty, and why the proposals in the writings under review are often irrelevant or even harmful.

\section{Policy and Poverty in Pakistan}

\section{The Period of Ayub Khan}

In Pakistan the government only began to affect the distribution of income actively after the boom in commodity prices caused by the Korean war ended in 1953. While the boom lasted Pakistan enjoyed a degree of prosperity it has never had again; export earnings were higher, in dollar terms, than at any time until the 1970 s and imports were abundant. When the boom ended, the fall in commodity prices reduced export earnings so far that the government felt obliged to impose restrictions on imports. This was the first positive step the government took to alter income distribution; demand for consumption goods exceeded supply, prices rose in spite of price controls and the distribution of income shifted, with profits taking a larger share. 
The shift was accentuated by the government policy of the next few years of giving priority to industrialisation, notably cotton and jute textiles. Domestic production received almost total protection. For instance, imports of cotton cloth were almost entirely stopped and, since local industry hardly existed at all at that time, those who were able to set up textile mills made such big profits that they could usually recoup their investment within a year.

The balance of payments, nevertheless, continued to deteriorate until, on the advice of German experts, the bonus voucher scheme was introduced to forestall a crisis. The bonus voucher was an entitlement to purchase foreign exchange at the official exchange rate of Rs. 4.5 to the US dollar, and the scheme allotted these vouchers to exports of most kinds of manufactures in proportion to the value of the exports. The vouchers could be sold on the market and, since all foreign exchange had to be surrendered to the State Bank of Pakistan and since foreign exchange to import most non-essential goods had to be bought using the vouchers, they fetched a price termed the premium. For example, cotton textile exports might be allotted bonus vouchers equivalent to 30 per cent of their export value. So, for an export of cotton textiles equal to Rs. 100, calculated at the official exchange rate, the exporter would get bonus vouchers for Rs. 30, in addition to the Rs. 100 obtained when he surrendered his foreign exchange to the State Bank. Usually the premium ranged between 130 and 180 per cent, which meant that the exporter received an additional Rs. 39 to 54 from selling the vouchers. Since exports of raw materials were not allotted bonus vouchers, their domestic prices remained determined by the official exchange rate. The exporter benefited from a dual exchange rate. The importer, however, had to pay Rs. 230 - 280 to import goods worth Rs. 100 at the official exchange rate and this cost was passed on to the consumer.

The effect of the scheme was to subsidise exports at the expense of consumers. Since the consumers of non-essential imports were mostly the middle classes, the scheme caused an income transfer from middle class salaries to industrial profits. Goods that are not necessarily luxuries for the middle class, such as cars, motorcycles, watches and air conditioners, were not classified as essential and had to be bought with bonus vouchers.

The effect of bonus vouchers on profits was addictive. The German experts had warned that the scheme was just an emergency measure to stimulate exports of manufactures and should be ended as soon as possible. It was not an auction mechanism for balancing the demand for foreign exchange against the supply, because the premium stayed in the private sector and the demand was merely transferred from one person to another. A balance would have required that the premium accrue to the state and not be spent. As it was, excess demand for foreign exchange continued, 
sometimes pushing the bonus voucher premium to 200 per cent but never letting it fall to 100 per cent. The increase of profits caused by this transfer was so great that it was possible to export profitably even when the foreign exchange value of the exports was less than the foreign exchange cost of the inputs used to make them, what was termed negative value added at international prices. Then exports cost more foreign exchange than they earned. By the early 1960s some economists calculated that a number of Pakistan's exports, including cotton and jute textiles, were earning less foreign exchange than they cost. Nevertheless, neither the industrialists nor the Ayub Khan regime, which had close links to them, saw that as a reason to give up a scheme that yielded such generous profits.

Whether or not the government and its planners understood that the bonus voucher scheme was not much other than a means for transferring income from middle class consumers to industrialistis, it fitted well into the economic strategy of the Ayub Khan regime, of which the most important element of the strategy was rapid industrialisation stimulated by high profits. Several methods were used, apart from the bonus voucher scheme, to keep profits high, including almost total protection against competition from imports, large amounts of financing at low interest rates, tax privileges. Trade unions were suppressed or rendered ineffectual in order to prevent higher wages and better working conditions from affecting quick profits.

Apart from the obvious purpose of being an incentive to investment, the favouring of industrial profits had the purpose of increasing saving. The theory was that people with higher incomes saved more than people with lower incomes, so concentrating national income with a small set of people would raise the national saving rate. This was evident in the Second Five Year Plan (1960-65). The Plan practically ensured that the consumption per head of most; of the population would not rise. It aimed at an increase of consumption per head of all the population of slightly more than one percent per annum and proposed to 'keep the increase in consumption in check' $^{\text {'1 }}$ by higher indirect taxes 'of a kind which reach ordinary incomes' ${ }^{2}$. Since the rise in the saving rate was largely in the private sector, it could only be achieved by increasing income inequalities, which meant that the increas $43 \mathrm{e}$ in consumption per head would mostly be confined to the better off.

Such policies did not shock economists at the time. The Planning Commission was being advised by the Harvard Advisory Group and the

\footnotetext{
${ }^{1}$ Second Five Year Plan (1960-65) p.57

${ }^{2}$ Second Five Year Plan (1960-65) p.27
} 
theory behind the Second Plan was expounded by Mahbub ul Haw in his book "The Strategy of Economic Planning" ${ }^{3}$ In this book he contrasted the choice between less hardship at the start, but less saving and slower growth, with more hardship at the start and faster growth. The former he called the Rostow model and the latter the "Russian" model. Haq shared the widely held opinion that the accumulation of capital in the industrial countries in the 19th century was achieved by keeping the income of most of the population low, though he does not explain why the same hardship should be necessary now, when the techniques of production are much more advanced. His advocacy of the "Russian" model led him to assert that 'social services should be given less emphasis' because 'it would be unfortunate' if a change 'in growth philosophy of economies still at this stage of "take-off" were to occur. ${ }^{4}$ The object of the hardship was a marginal saving rate 'generally between 30 to 40 per cent. These rates are quite high and have not yet been achieved outside communist countries for a sustained period of time." Such an achievement could not be seriously presented without believing that there was a means of bringing it about, especially since the saving rate had dropped during the period of the First Plan. Haq refers to a study that showed that "Pakistani industrialists ploughed back 75 to 80 per cent of their retained income into investment if they could get complementary inputs like foreign exchange." The only way of getting near the desired saving rate was redistribution of income in their favour.

\section{Freer Markets and More Poverty}

\section{The New Policies and the Critics}

Economic policies changed little while the Ayub Khan government lasted, except for an increase in the emphasis on agriculture, though western economists and sources of foreign aid at the time were growing concerned that the developing countries were not becoming less dependent on aid and that the living conditions of the poor were not improving. For this they blamed the inefficiency of the industries protected by high trade barriers and the lack of interest of the governments, the owners of the industries and the wealthy land owners in social development. The development policies of the World Bank shifted progressively to improving the conditions of the poor and allocating resources better by freeing markets, and other donors followed it.

\footnotetext{
${ }^{3}$ Mahbub ul Haq. The Strategy of Economic Planning. Oxford. 1963.

${ }^{4}$ Mahbub ul Haq Op.cit. pp. 3 \& 35

${ }^{5}$ Mahbub ul Haq Op.cit. pp.65

${ }^{6}$ Mahbub ul Haq Op.cit. pp.23
} 
With variations, these are the policies that have dominated development assistance and government policies in most developing countries, very much so in Pakistan, for the last three decades. They have brought attention to the persistence of poverty but have had no more success than the earlier policies in reducing it in Pakistan or anywhere else. On the contrary, the failure has been so great that there is now a widespread tendency in the developed and developing countries to blame poverty on the World Bank, which has for so long made it its prime concern, and on the IMF, which influences macroeconomic policies more, although it, too, has begun to profess concern.

The critics of these institutions are too diverse to have a line of reasoning in common. Some are uninterested in economic theory but react to what they understand to be the effects of the application of the advice of the World Bank and the IMF, unemployment, reduced wages and less provision by the state of social services and subsidies directed to the poor. Such criticism has two limitations one is a limitation that the World Bank and IMF emphasise, namely that the effects blames on them by the critics are usually the consequences of the governments' imprudent macroeconomic policies and that worse would have followed if the institution had not come to the rescue.

The second limitation is that the critics argue from appearances, but have no coherent economic theory and policy of their own. The World Bank and IMF have the advantage of having a standard set of development policies to recommend, namely liberalising trade and domestic markets, privatisation and prudent macroeconomic balances. To this the critics can reasonable reply that the countries that implemented the reforms recommended by the two institutions seem rarely to reduce poverty and avoid more crises of the type that obliged them to seek these institutions' help at the start; too often these institutions praise countries for their following their policies only to criticise them later, when they fall into difficulties again, as with Mexico and Ghana7 in the early 1990s. Nevertheless, not having something to propose against the World Bank and the IMF, the critics are at a disadvantage.

The orthodox economist who wishes to criticise the World Bank of the IMF can not attack their theories or policies since these institutions follow the same text-books as he does. He must attack the way the institutions work, namely their objectives, quality of analysis and implementation, costs, organisation, procedures, secrecy and so on, none of which need be discussed here. As to whether or not the World Bank and IMF, or any other multilateral institution, alleviates or worsens

\footnotetext{
${ }^{7}$ For a description of how the World Bank changes its views on Ghana, see Mkandawire and Soludo, p. 84
} 
poverty by the policies they propagate, the orthodox economist's views can differ little from theirs, so he must advocate the same policies regarding markets and macroeconomic stability as they do and maintain either that these policies do not hurt the poor in the long run, or that they actually benefit them.

\section{Exchange rate Movements and their Effects}

In doing so, the World Bank, the IMF and the orthodox economist, deliberately or not, ignore the effects of the exchange rate policies they advocate. In 1973 the developed countries were forced by the growth of international capital flows to abandon the system of fixed exchange rates with which they had enjoyed higher sustained rates of growth and less unemployment than before or since. Floating rates became orthodox and, though several European countries tried to maintain fixed exchange rates among themselves, in time the developing countries were made to believe that the correct thing to do was either to let their exchange rates float or to adjust them frequently, always by devaluation.

The theory is that devaluation lowers the domestic cost of production relative to the prices of imports and exports. But the operation of the market causes domestic prices of traded goods to adjust to the prices of imports and exports, and the prices of untradable goods must also adjust as the prices of their direct and indirect traded inputs rise. No such market mechanism causes the nominal price of labour to rise, so the real wage declines, unless workers can persuade employers to raise them. And if they succeed in raising their nominal wages to offset the price rise, the effect of devaluation on the cost of production is cancelled at the cost of a rise in prices. Hence, a successful devaluation is one which results in a fall in real wages, at least in the tradable goods sectors. Then, if a decline in production does not follow, GDP stays constant in real terms and the share going to profits increases.

The purpose of devaluing a currency is to lower the real wage, though the official argument is that devaluation offsets domestic inflation, which would, otherwise, make Pakistan uncompetitive in world markets. To state the official argument more precisely, Pakistan's exports and importers have little influence over the prices they get or pay for their goods, so, if production costs rise too far, the profit margins of domestic producers of tradable goods fall to zero. (One can ignore the possible intermediate stage when exporters try to sell in the domestic market and lower the profit margins there.) 
The argument may be valid, but actual practice does not conform to it. The argument implies that independent experts study the domestic costs of production and compare them with costs and prices in other countries, and that the decision to devalue is based on their conclusions. This is, of course, not what happens, nor does anybody imagine that it does. Rather, officials make broad comparisons of domestic inflation with some measure of international inflation, or inflation in other suitably chosen countries, and assume that there is a case for devaluation if the former is the higher.

Such comparisons of inflation are just comparisons of the movements of price indices and can not substitute for direct comparisons of costs and prices. Inflation means a general rise in prices and the indices used to measure it are broad based, whereas devaluation acts specifically to lower real wages and salaries. Following devaluation the domestic prices of tradable goods can be expected to adjust to their earlier relation to import and export prices, provided trade barriers do not change. The prices of untradables that have tradable direct or indirect inputs must also rise; for instance electric power may require imported oil and transport uses fuel and spare parts. This is the familiar inflationary effect of devaluation. By reacting to inflation, instead of studying the costs of production, the authorities are led to devalue again, even if the nominal wages has not risen.

The decision to devalue should, therefore, depend on the answers to two questions: how are nominal wages and salaries expected to react and how much does inflation have causes other than devaluation? If nominal wages do not rise as much as prices, at least in the tradable goods sectors, devaluation is considered to be successful. In this case the production costs of tradable goods have fallen relative to prices in export and import markets because the cost of labour has fallen relatively, i.e. the real wage is lower. But, if because trades unions are strong or for other reasons, nominal wages in the tradable goods sectors catch up with prices, the costs of production will be lower only for the time before wages have caught up. In this case the gain to profits in the tradable goods sectors is transient and the real incomes of those who can not raise their wages or salaries to match decline.

The answer to the second question, how much inflation may be due to causes other than devaluation, is theoretically straightforward. The common argument, that government deficits and money creation must cause prices to rise, though true for the closed economy, fails to hold for the open economy to the extent that the domestic prices of tradable goods are determined by export and import prices. If the economy is open, the increase in monetary demand relative to the supply of goods is met by an increase of imports or reduction of exports, whose prices are determined outside the domestic economy. Hence, with a constant exchange rate, 
domestic price movements in the open economy only occur within the limits allowed by obstacles to trade or are the results of price movements outside, and increases or decreases in demand relative to supply are accommodated by the balance of trade.

Nevertheless, orthodox economists and institutions like the IMF and the State Bank of Pakistan try to prevent prices of goods and nominal wages from rising after devaluation. The reasoning is not clear, since they also believe that, for economic efficiency's sake, domestic prices of tradable goods should be determined by world prices. To keep prices and nominal wages from rising, they take the usual deflationary measures, raising interest rates and restraining the growth of bank credit and supply of money. These measures may alter the pace at which domestic prices adjust to export and import prices, but they can not prevent the adjustment. When prices rise faster than the volume of credit or supply of money, unless there is a change in the way firms finance their activities and a rise in the velocity of circulation of money, both of which can normally be ruled out, the outcome is a decline in economic activity, a recession. Almost always the effect of deflationary measures is to reduce investment, which results in an improvement in the balance of trade if saving does not fall by the same amount. Since a recession leads to higher unemployment, workers are less able to raise their nominal wages and the real wage declines. This is the familiar outcome associated with IMF programmes.

What orthodox economists, the IMF and the World Bank hope from a recession is that reduced domestic demand will lead to more exports and fewer imports, part of which is commonly achieved by the fall in investment. But the cost in terms of lost growth and unemployment is so high that officials and politicians often allow common sense to prevail over economic doctrine by letting the supply of money expand to accommodate, at least partly, the rise in prices. Devaluation thus leads to an increase in the money supply.

\section{Devaluation, inflation and the supply of money}

The official view of the SBP is that inflation is caused by the growth of supply of money, a view it believes to be substantiated by a study by Dr. Anjum Nasim, "Determinants of Inflation in Pakistan". The study states that 'money supply would appear to be a key determinant in an economy, ${ }^{8}$ that 'the empirical results suggest that that monetary expansion is one of the main explanations in Pakistan" and that 'this study provides strong empirical

\footnotetext{
${ }^{8}$ Nasim. Op.cit. p.1.

${ }^{9}$ Nasim. Op.cit. p.2.
} 
evidence that to lower rates of inflation, monetary expansion has to be curtailed and output growth encouraged'. ${ }^{10}$

Although the study appears to put money supply as the main explanation of inflation, its data lead rather to the conclusion that the main explanation of inflation is the movement of import and export prices as determined by the exchange rate and inflation outside Pakistan. Already, the first few pages lead to that conclusion. In a chronology from 1970 to 1995 (pages 2-6) high inflation in Pakistan is always associated with devaluation or high international inflation and low inflation with a stable exchange rate and low international inflation. The association with money supply is not as close; in certain periods $(1977-79,1982-83,1992-93)$ inflation and money supply did not move together. Visual inspection of the study's diagram (Fin.1.b) plotting the consumer price index and the rupee prices of tradable goods (a proxy for international prices) over time shows that the CPI follows the tradable prices with a short lag. No such relation is apparent in the diagram giving the CPI and the money supply (Fig.1.d), rather it is the contrary movements that stand out.

How do the econometric exercises yield results at variance with logic and appearance? Like the senior officials of the SBP, the present author studied econometrics before the co-integration relations, Dickey-Fuller and Phillip-Perron tests and Engle-Granger two step procedures used in the study had been invented. So a detailed evaluation of the econometrics is not given here.

The numerical results need not be questioned, but they do not lead to the apparent conclusion that the growth of money supply is the main explanation of inflation, or any explanation at all. The two significant determinants of inflation given by the econometric estimates, money supply and international prices in rupees, an indirect cause of inflation, or it can be caused by inflation. The study recognises the possibility; it points out that an expansion of money supply can lead to a worsening of the trade balance, to which the authorities react by devaluing, which causes inflation. ${ }^{11}$ From this arises the possibility of 'simultaneity bias', for which the study can give no definite answer. ${ }^{12}$ To assert that this connection makes money supply a determinant of inflation, as the study seems to do, is wrong, for an alternative to devaluation is to act on the cause given for the trade deficit and reduce it by reducing domestic demand. It is the better course, since devaluation, by itself, does not reduce the excess demand that caused the

\footnotetext{
${ }^{10}$ Nasim. Op.cit. p.20.

${ }^{11}$ Nasim. Op.cit. p.34.

${ }^{12}$ Nasim. Op.cit. p.35.
} 
deficit, but merely transfers income from wages and salaries to profits. Not distinguishing between direct and indirect causes is a specification error. In this cases the increase in the supply of money need not result in inflation. If, like some of the East Asian or major industrial economies, Pakistan had foreign exchange reserves equivalent to a few years' imports, the expansion in money supply need not prompt the authorities to devalue, and the lack of reserves becomes as good an explanation of inflation as the money supply.

The study does not refer to the other possible connection between money supply and devaluation, mentioned earlier, that devaluation causes prices to rise and that the authorities prefer accommodating the higher prices by expanding the supply of money to causing a recession. The study appears to exclude this possibility on the grounds that prices adjust to money supply. It does not explain how this view can be reconciled with the view it also expresses, that the domestic prices of tradable goods are determined by international prices, but follows the argument of Friedman that, if the price of one good rises, it leaves less to be spent on other goods, whose prices must, therefore, fall. ${ }^{13}$ The possibility that, not the prices, but the volume of sales goods falls is ignored. By this reasoning a recession can never be caused by restraining the supply of money or bank credit, a conclusion that Friedman wanted to reach but not one that accords with experience or that is accepted by most economists and central bankers.

The foregoing discussion of the effects of devaluation can be summarised simply. The prices of tradable goods are determined by the prices of exports and imports and the prices of untradable goods by the prices of their tradable inputs, the rate of return on capital and the nominal cost of labour. If the nominal cost of labour does not rise as much as the prices of tradable goods, the rate of return on capital rises. Hence, the only way devaluation can reduce the costs of production of tradable goods relative to their export and import prices is by lowering the cost of labour relative to the prices of tradable goods. Devaluation may be advisable if the domestic costs of production of tradable goods are too high to yield a profit, but it is inflationary and, since the decision to devalue is taken on the basis of inflation, rather than on the study of production costs, one devaluation leads to the next and the real income of labour falls each time. An expansion of the money supply can be associated with devaluation in two ways. One is that money supply is increased to accommodate the higher prices, rather than force a recession. The other is that an increase in money supply increases the demand for goods relative to the domestic supply and worsens the trade balance - not raises prices of tradable goods, since they are determined by export and import prices - to which the authorities react with

\footnotetext{
${ }^{13}$ Nasim. Op.cit. p.10.
} 
devaluation. Hence a spurious correlation of money supply with inflation, which is interpreted by the authorities as the explanation of inflation.

Devaluation has other effects that harm the economy. Once the expectation of repeated devaluation has been established, as in Pakistan, holders of monetary wealth have an incentive to convert their money into sounder currencies, which usually means transferring it out of the country. The result is a continual outflow of capital. Devaluation also raises the replacement cost of capital goods relative to historic cost, which, since depreciation is calculated on the basis of historic cost, means that the depreciation funds of manufacturing firms do not suffice for replacement. These firms must, therefore, borrow to replace their capital stock and increase their debt:equity ratios. Inflation also reduces the real value of savings, which hurts the poor most of all, since they are the least able to obtain rates of return on their financial assets that compensate for inflation.

Ultimately, the motive behind devaluation is psychological. Devaluation is the sign of being underdeveloped, a symbol of status. Respectability in the eyes of the officials of developed countries and international institutions comes from conforming to one's standing in the hierarchy of economic power, and a country that does not devalue from time to time brands itself as presuming to ape the developed countries. The proof is given by the reaction of officials in developed and developing countries when international inflation causes domestic inflation. According to the same theory as determines that countries should devalue to offset domestic inflation, they should revalue to offset international inflation. But, however much officials lament over domestic inflation that is no fault of the country, they scorn any suggestion that the country should revalue - that would be impudence.

The depreciation of the international exchange value of the Pakistani rupee is not, of course, the sole cause of the persistence of poverty. An example of how poverty can be generated with the exchange rate fixed was given by the Ayub Khan government's policies in the 1960s. moreover, the lack of attention to education and the social sectors that was virtually institutionalised by that government can be said to be a contributory cause in the sense that, had the attention been greater, poverty now could have been expected to be less. But poverty could also have been expected to be less despite the neglect of education and the social sectors; more income could have been expected to "trickle down". What the effects of depreciation of the rupee do is help answer the question, why did poverty persist so much, despite economic growth, after governments had stopped deliberately trying to make income distribution more unequal? 


\section{IV. "Social Development in Pakistan" and "Human Development in South Asia”}

SDP and HD illustrate the limitations of treating poverty with neoclassical economic theory. Although both make many proposals regarding specific problems faced by the poor and regarding the general running of government, neither has a convincing plan for altering the distribution of income. Neither explains how income growth can be made to "trickle down". As a rule the proposals of the first, specific type are likely to better the conditions of the people they are meant to help, if well implemented, and, applied together on a large scale, could make life better for much of the population. But they do not remove poverty, they only help make it more bearable. Of the second type of proposal, some are vague or general suggestions whose practicability is doubtful and some have no obvious relation to the problems of poverty or social development, but are part of the economic and political agendas of the publications. Rather than give a lengthy exposition, just a few examples are provided of the two types of proposals.

Among the 'institutional reforms in social service delivery' in SDP's chapter on the Social Action Program, the proposals for elementary education include non-formal basic education, basic community schools and home schools. ${ }^{14}$ These schemes can not be objected to, given the present state of education. But they are desperate measures for a desperate situation, not an education policy for the long run. Similarly, strengthening Zakat and the Bait-ul-Maal is merely to make charity a government obligation, not a measure to reduce the need for it. The same is true for the proposals for a rural works programme and directed food subsidies. ${ }^{15}$ Schemes such as these will be needed for a long time, even if economic growth accelerates and incomes "trickle down" more, but they are palliatives, not cures.

Without having tried to explain the persistence of poverty using economic theory, SDP and HD advocate free market policies among their proposals of the second, general, type. What is a political choice is presented as the will of the people; according to HD, "There is a broad consensus in South Asia that a liberal economic framework in which critical prices reflect their scarcity values and in which the private sector is afforded maximum opportunities to operate freely, is in the best interest of longterm development, provided markets can be regulated in the best interests of the less privileged. ${ }^{, 16}$ No evidence is given and many would be surprised if it were true. But, even if it were true, few economists, least of all the World Bank and the IMF, would accept that economic policy should be

\footnotetext{
${ }^{14}$ Social Development in Pakistan. P.74.

${ }^{15}$ Social Development in Pakistan. P.113-4.

${ }^{16}$ Human Development in South Asia, 1999. P.34.
} 
determined by consensus. One could also retort that, if put to a vote, the caste system would have a majority in favour. In any case, whatever meaning the statement might have is removed by the proviso: if such regulation is not possible, as is likely, would the authors advocate another system?

Both SDP and HD advocate trade liberalisation and refer to profits of protected industries as "economic rent". Yet, apart from Britain and Hong-Kong, no economy has industrialised without protection. Britain, being the first to industriealise, had the most advanced industry until the late nineteenth century and so it believed in free trade. The other countries that have industrialised protected their industries from British competition, because they knew that they would otherwise never industrialise. HongKong's circumstances were unique and not relevant to other countries. The World Bank, IMF and many economists point out that in most developing countries the industries that flourished under protection never became efficient, let alone internationally competitive, and draw the conclusion that protection is necessarily bad. A better conclusion is that the problem, one which each country must solve for itself, is how to ensure that the protected industries eventually become reasonably efficient, a problem the East Asian economies understood but neo-classical theory does not.

A relation exists between liberalisation of trade and poverty in developing countries: the former causes the latter. Almost all liberalisation programmes imposed by the World Bank and the IMF have been followed by permanent falls in the level of investment. What the devaluations that accompanied the reforms did not do to increase poverty, unemployment did. In Latin America, where the reforms have gone furthest, economic growth has been slow and unsteady, capital has been flowing out and poverty has been spreading. HD asserts, with no mention of a source, that trade liberalisation would add nearly 5 per cent to GNP. Well known neo-classical economists have tried to estimate the gains to be expected from liberalisation and have found them to be minimal. ${ }^{17}$

Another proposal of the second type advocated by HD is the proposal 'for empowering the poor through the provision of micro-credit'. ${ }^{18}$ It argues that 'the experience of the Grameen Bank in Bangladesh has demonstrated that the poor are good savers and investors, and they are eminently creditworthy', that 'access to credit should be treated as a fundamental human right' and that bankers 'should take a chance on the future potential of the people'. All this may be oversimplifying. Even if the Grameen bank and similar institutions in other countries have worked out how micro-credit schemes can be made to work under the right conditions,

\footnotetext{
${ }^{17}$ Among several studies are those by Dornbusch and by Rodrik.

${ }^{18}$ Human Development in South Asia, 199. P.146.
} 
they are specialised and their scope is limited. HD does not explain how private banks would be induced to extend micro-credit, so presumably the banks that 'should take a chance' are in the public sector. In any case, HD proposes that 'the credit needs of the poor could be met by recovering defaulted loans from powerful businessmen and influential politicians' and those loans were made by public sector banks.

The general proposals also include some that are openly political and far-reaching. Among them is decentralisation, which HD describes as the second most crucial step', after representative democracy, 'in empowering people ${ }^{, 19}$. Both SDP and HD assume that government administration is responsive to ordinary people, especially the poor, only if under locally elected politicians. Plausible as it sounds, it is belied by experience all around the world. Decentralisation is popular in the developed countries these days, but in the history of Europe and Japan it was the emergence of strong central governments that broke the local power of the feudal lords. In the US it is the federal government that reduces income disparities and protects the rights of minorities; state governments tend to aggravate inequalities and weaken minorities, and counties are still worse. That is why the struggle over state rights is so bitter. HD recognises that local governments may 'further empower elites rather than ordinary people', but can only offer vague suggestions, such as 'positive discrimination' to counter the danger. That the successful East Asian countries all have strong central governments, HD omits to mention.

Both publications go further to advocate devolving government responsibilities to NGOs. ${ }^{20}$ It seems to be a rule that NGOs acquire more importance in countries whose economic and social development have been disappointing, unless they are suppressed by an authoritarian state. Pakistan, like many developing countries, has become dependent on them and it is tempting to imagine that they could take over some of the responsibilities that the present administrative system seems incapable of carrying out satisfactorily.

These two proposals are representative of many people who believe that the decay of the state has gone so far that improvement can only come from by-passing it. They place their hopes in local government and the selfhelp stimulated by and charity provided by NGOs. In effect they advocate a weak government. A less optimistic view of the outcome is that it could end in anarchy and civil war. Many NGOs have political and religious affiliations that do not fit into the benign tolerance SDP and HD seem to assume. Both

\footnotetext{
${ }^{19}$ Human Development in South Asia, 1999. p.51. Social Development in Pakistan. p.78-9.

${ }^{20}$ Human Development in South Asia, 1999. Ch.7. Social Development in Pakistan. p.68-89.
} 
in Egypt and Turkey the religious parties have gained their popularity because they genuinely cared for and looked after the poor, but their political aims are not those of the institutions behind these two publications. What the combination of weak government, strong NGOs and the unending parochialism in many parts of the country could lead to is not easy to predict, but it could be disastrous.

Nevertheless, the publications bring out what may be the most important question of all, which is, the choice between strong, efficient government and decentralisation managed by local politicians and NGOs. Strong government is not necessarily unrepresentative of or unresponsive to the people, as SDP and HD seem to imply, but it presupposes a wide range of reforms, especially of the civil service, business procedures, judiciary, police and so on. If this seems too much to ask for, the alternative is what the publications under review propose.

\section{Substitutes for Good Theory}

Both SDP and HD try to compensate for the lack of sound theory, the former by its economic model and the latter by the invention of the concept of humane governance.

\section{"The Integrated Social Policy and Macroeconomic Manning Model}

To some economists and many non-economists the SDP's economic model might appear to replace the need for coherent analysis. Models give the impression of showing how things actually work, though all they do is reproduce the opinions and preferences of their authors. People who do not have much experience of economic models believe that those who use them obtain their results by putting in objective data for the past and present and making suitable assumptions about the future, e.g. regarding the prices of exports or the inflow of foreign financing, and then letting the model reveal the consequences. In practice, as anybody who has worked extensively with economic models knows, merely feeding them data and reasonable assumptions almost always gives absurd results. The economist must run the model many times, modifying the assumptions, altering its equations and, as a last resort, manipulating the data before sensible results emerge. The more complicated the model (rich specifications in the parlance of SDP) the more effort goes into getting the results right. Just like its equations, the model's results merely reflect the opinions and preferences of the user.

The lack of any clear economic theory is evident from the equations of the model. An illustration is the discussion of the effect of devaluation. SDP asserts that it 'increases the relative price of capital goods (which are imported) and thereby discourages private investment'. Relative to what the 
price increases is not clear, but having just stated that depreciation raises domestic prices, it seems that it means relative to the price of labour. Normally, in neo-classical economics, this relative price movement is assumed only to alter the factor intensities or choices of techniques, not the amount of investment. Moreover, the rise of prices of goods relative to the nominal wage causes a more than proportional rise in the profit margin and, hence, in the return on capital. Devaluation gives more incentive to invest by reducing the real wage.

Not enough information is given to judge the other relations assumed, but, the behaviour equations, like the relation between investment and the exchange rate, are estimated from single equation regressions. According to econometric theory, when the same variables occur in several equations, i.e. when there are simultaneous equations, the correct procedure is to use simultaneous equation estimation. This is usually difficult, often impossible. But the difficulty or impossibility of using the correct method does not mean that the wrong method gives the right results; single equation estimates can not be used and the estimates they give are meaningless. Economists who use them incorrectly in this way usually plead that they have heuristic value or are approximately correct, though there is no reason to believe either to be true. Single equations regressions would be illegitimate even if the results appeared to be statistically significant, though SDP says nothing about the results of significance tests. One advantage of using simultaneous equation estimation is that it sometimes exposes illogical or inconsistent assumptions; the attraction of single equation estimation is that it does not.

\section{Humane governance}

HD presents the problems of social development in South Asia and, more particularly, in Pakistan as problems of governance; the subtitle is "The Crisis of Governance". Governance has been a preoccupation of the World Bank for some years now, because interest has grown in understanding how institutions determine the formulation and implementation of policies, as well as the routine conduct of business. It is mainly concerned with institutions and organisations, and much of it derives from the ideas of principal:agent transactions. But, as happens to many words that become fashionable, its meaning has been stretched. By the time it is defined as 'the sum of the many ways individuals and institution, public and private, manage their common affairs ${ }^{21}$ not much meaning is left.

As a notion for the analysis of how societies or economies function

${ }^{21}$ Part of the definition by the Commission on Global Governance, quoted by Human Development in South Asia, 1999. p.29. 
and how policies are formulated and implemented, governance in the narrow sense involves no judgement as to whether a particular outcome is desirable or not; it tries to explain outcomes by the way institutions work. When the degree of desirability of outcomes is specified, governance can be good or bad, but governance as the operation of institutions and the degree of desirability of the outcomes remain distinct. In HD's notion of humane governance the distinction is lost; it is a political and economic agenda of the authors. Much of it would not be disputed in the western liberal scheme of values: human rights, impartial judiciary, equal rights, corporate social responsibility, etc. These are moral imperatives. But, when humane governance includes removal of rent seeking, HD is presenting free market economics as though it were on the same moral plane as human rights. Similarly for decentralisation. Moralising has taken over.

\section{Summary}

Poverty has remained more widespread in most developing countries than would have been expected from their economic growth, and this demands an explanation. Neo-classical economic theory helps little, since it attributes income distribution to the technical features of production, unless there are market failures. Its two remedies, therefore, are income transfers through taxes and correcting the market failures. The first risks inefficiency, while market failure is not a convincing explanation of widespread poverty. The alternative to neo-classical theory is that policies have been the cause of poverty. It was obvious in the time of the Ayub Khan government, which was virtually explicit that its policy was to concentrate income. Since then policies have changed, yet poverty persists. The change all over the world has been to freer markets and flexible exchange rates. Devaluation, or gradual depreciation of a currency, is intended to improve the trade balance, but it works through lowering the nominal cost of labour in terms of foreign exchange, and hence the real wage. It also causes inflation, since domestic prices of tradable goods rise along with import and export prices. Since the authorities react to inflation with more devaluation, regardless of what has happened to real or nominal wages, the country is caught in a cycle of repeated devaluation and inflation. Orthodox economists and institutions, like the World Bank and the IMF, are unable to offer effective remedies for poverty because neo-classical theory does not provide any, so they can only talk about palliatives and market reforms that actually make things worse. 
156 The Lahore Journal of Economics, Vol.5, No.1

\section{References}

Dornbusch, Rudiger. The Case for Trade Liberalization in Developing Countries. Fournal of Economic Perspectives 6(1): 69-85. 1992

Government of Pakistan. Second Five Year Plan, 1960-65.

Haq, Mahbub u1., 1963. The Strategy of Economic Planning: A Case Study of Pakistan. Oxford University Press.

Haq, Mahbub u1.. The Human Development Centre, Human Development in South Asia 1999. The Crisis of Governance. Oxford University Press.

Mkandawire, Thandika and Charles C. Soludo., 1999. Our Continent, Our Future: African Perspectives on Structural Adjustment. Council for the Development of Social Science Research in Africa. Africa World Press, Inc.

Nasim, Dr. Anjum. Determinants of Inflation in Pakistan. State Bank of Pakistan, 1997.

Rodrik, Dani. The New Global Economy and Developing Countries: Making Openness Work. Overseas Development Council, Washington D.C. 1999.

Social Policy and Development Centre. Social Development in Pakistan. Annual Review. 1999. Social Development in Economic Crisis. Oxford University Press. 